\title{
EFFECT OF INTRAVITREAL TRIAMCINOLONE ACETONIDE IN REFRACTORY DIABETIC MACULAR EDEMA
}

\author{
Anwar Ahmed Gul, Ume Sughra, Kashif Habib, Zeeshan Khan Ozeer Khan \\ Al-Shifa Trust Eye Hospital, Rawalpindi Pakistan
}

\begin{abstract}
Objective: To investigate the effects of intravitreal triamcinolone for refractory diabetic maculopathy after 03 unsuccessful intravitreal bevacizumab injections.

Study Design: Prospective observational study.

Place and Duration of Study: Retina department of Al-Shifa Trust Eye Hospital Rawalpindi, from Jun 2016 to Jul 2017.

Methodology: Total 35 eyes of 35 patients who were diagnosed with diabetic maculopathy and having history of minimum three intravitreal Bevacizumab injections were included. Detailed eye examinations included visual acuity, anterior and posterior segment examination and intraocular pressure measurement was performed in all patients. Central macular thickness was also measured. Then intravitreal triamcinolone was administered to eyes by principal researcher (Ophthalmologist). After one month, follow up examination of patient's eyes was done to assess the effects of injection.

Results: Majority of the participants were males $19(55 \%)$ in this research. There was statistically significant difference between means of intra ocular pressure (mean difference $=4.30 \pm 5.41$ ), Visual acuity (mean difference $=2.8 \pm 2.4$ ) and central macular thickness (mean difference $=236.4 \pm 13$ ) pre and post injection was found $(p$-value $<0.05)$.

Conclusion: There was statistically significant difference of central macular thickness and visual acuity, pre and post intravitreal triamcinolone acetonide injection was found.
\end{abstract}

Keywords: Central macular thickness, Diabetic macular edema, Diabetic retinopathy, Diabetes, intravitreal bevacizumab, Intravitreal triamcinolone acetonide.

How to Cite This Article: Gul AA, Sughra U, Habib K, Khan ZKO. Effect of Intravitreal Triamcinolone Acetonide in Refractory Diabetic Macular Edema. Pak Armed Forces Med J 2021; 71(5): 1861-1864. ～doi: https://doi.org/10.51253/pafmj.v71i5.5305

\footnotetext{
This is an Open Access article distributed under the terms of the Creative Commons Attribution License (https://creativecommons.org/licenses/by-nc/4.0/), which permits unrestricted use, distribution, and reproduction in any medium, provided the original work is properly cited.
}

\section{INTRODUCTION}

Diabetes is a long-standing disease caused by inability of the pancreas to produce enough insulin. Raised blood glucose level in body damages blood vessels, eyes, kidneys, heart and nerves. Due to increase in associated risk factors like obesity, sedentary life styles and use of refined foods, diabetes has almost reached two folds since 1980 in the adult population. Globally, an estimated 422 million adults were living with diabetes in 2014, compared to 108 million in 1980.1,2

Patients with diabetes are more prone to the risk of visual loss due to secondary eye diseases. Secondary eye diseases due to diabetes are diabetic retinopathy (DR), macular edema, glaucoma, and cataracts. Early identification and treatment of DR can prevent $60 \%$ of the visual loss due to DR. In the initial phases, patients with retinopathy are usually asymptomatic and they may not look for an examination at that time. Over one-third of an estimated 285 million diabetic people worldwide had signs of DR in 2010, and a one third of

Correspondence: Dr Ume Sughra, Associate Professor of Ophthalmology, Al-Shifa Trust Eye Hospital, Rawalpindi Pakistan Received: 11 Sep 2019; revision received: 12 Jul 2021; accepted: 27 Jul 2021 these suffered with vision-threatening diabetic retinopathy (VTDR). ${ }^{3}$ Diabetic macular edema (DME) is a sight-threatening complication of DR, occurring in up to $12.3 \%$ of patients with DR in certain populations. Prevalence of DMR increases with advancing stages of retinopathy. ${ }^{4,5}$ Thus, the treatment of DME remains a central and often a difficult challenge for many ophthalmologists. ${ }^{6}$

The early treatment DR study found that focal and grid laser photocoagulation reduces the risk of moderate visual acuity loss for all eyes with DME by as much as $50 \%$ compared with the observation group but with minimum vision improvement. ${ }^{7,8}$

Triamcinolone acetonide (TA) is a corticosteroid suspension that is used for the treatment of cystoid macular oedema, Proliferative diabetic retinopathy (PDR), Age-related macular degeneration (ARMD), Pseudophakic cystoid macular edema (CME) and cystoid macular edema associated with Retinitis Pigmentosa (RP). Favorable outcomes of IVTA has also been reported in the treatment of diffuse DME.9,10

Anti-Vascular Endothelial Growth Factor (VEGF) therapy is recognized as a prompt treatment of DME 
after numerous trials. Trials have showed its favorable outcomes. Although anti-VEGF therapy has dramatic outcomes, but not all DME patients respond to antiVEGF therapy. TA has been used to treat DME, both intravitreally and through posterior subtenon injection. In current study, we in-vestigated the effects of ITV refractory DME after 3 unsuccessful intravitreal bevacizumab (IVB) injections to improve the visual outcomes and decrease in macular thickness in cases not improving with IVB.

\section{METHODOLOGY}

A prospective observational study was conducted at Al-Shifa Trust Eye Hospital Rawalpindi from June 2016 to July 2017. The study was approved by Ethical Review Committee of hospital with a reference number of ERC\#55/AST/18. The central macular thickness mean values with standard deviation $(540.3 \mu \mathrm{m} \pm 96.3$ $\mu \mathrm{m})$ as measured by optical coherence tomography in the reference study were taken for sample size estimation. Putting these values in the WHO sample size calculator at $95 \%$ confidence level with $80 \%$ power of the study, the calculated sample size became 34.5 which was taken as $35 .{ }^{11}$

A total of 35 eyes of 35 patients were included and pre and post observations were recorded on them. Informed consent of the patients was obtained to enroll them in study. Both genders of all ages were included. Patients were selected through non-probability convenience sampling.

Inclusion Criteria: Patients diagnosed with diabetic maculopathy (DM) and having history of minimum three IVB injections were included.

Exclusion Criteria: Patients having history of trauma and any other ocular and systemic diseases were excluded.

First detailed eye examinations of all patients was performed which included visual acuity check with early treatment diabetic retinopathy study, slit lamp bio-microscope was used for anterior segment examination, and intraocular pressure (IOP) was checked with Goldmann Applanation Tonometer. After papillary dilatation, fundus examination was performed with 90 dioptre lenses. Central macular thickness was measured on a Heidelberg Spectralis OCT. Then IVT was administered to eyes by principal researcher (Ophthalmologist). After one month follow up, patient's eyes examination was done to assess the effect of injection. Visual acuity, IOP and macular thickness was checked and recorded. Data was collected using a structured proforma. All the findings at the time of injection and after one month were noted.

Data was entered and analyzed using SPSS20. The quantitative variables like visual acuity in Log Mar, IOP and central macular thickness were presented as means and standard deviations. Normality was assessed as a pre-requisite before applying parametric test of statistical significance. Data was found to be normally distributed with a KS statistics $>0.05$. Paired sample (dependent) t-test was applied to compare the means of pre and post IVB values of respondents. The $p$-value $\leq 0.05$ was considered significant.

\section{RESULTS}

Thirty-five eyes with pre and post values were included in this exposure series study. Majority of the participants were males $(19,55 \%)$ in this study.

Table-I shows the mean pre and post IVB injection values of visual acuity, intra ocular pressure (IOP) and central macular thickness.

Table-I: Pre and post values of intra ocular pressure, visual acuity and macular thickness $(n=35)$.

\begin{tabular}{l|c|c}
\hline & $\begin{array}{c}\text { Pre Intra Vitreal } \\
\text { Triamcinolone } \\
\text { (Mean } \pm \text { SD) }\end{array}$ & $\begin{array}{c}\text { Post Intra Vitreal } \\
\text { Triamcinolone } \\
\text { (Mean } \pm \text { SD) }\end{array}$ \\
\hline $\begin{array}{l}\text { Change in Intra } \\
\text { Ocular Pressure } \\
(\mathrm{mm} \mathrm{Hg)}\end{array}$ & $14.75 \pm 2.45$ & $19.05 \pm 6.37$ \\
\hline $\begin{array}{l}\text { Change in Central } \\
\text { Macular Thickness } \\
\text { (mm) }\end{array}$ & $514.5 \pm 132$ & $278.1 \pm 106$ \\
\hline $\begin{array}{l}\text { Change in Visual } \\
\text { Acuity (log mar) }\end{array}$ & $1.00 \pm 0.36$ & $0.71 \pm 0.25$ \\
\hline
\end{tabular}

Paired sample t-test showed there was statistically significant difference between means of IOP pre and post injection ( $p$-value $=0.002)$. Statistically significant difference of central macular thickness and visual acuity, pre and post injection was also found ( $p$-value $=0.001$ ) and ( $p$-value $=0.001)$ respectively. There was strong effect size for visual acuity, IOP and macular thickness according to Cohen's Criteria as shown in Table-II.

\section{DISCUSSION}

Triamcinolone acetonide is a corticosteroid and is generally used for the treatment of inflammation. In the current study central macular thickness was decreased in respondents after injection and similar findings were reported by a study conducted by Lashay et al, and William et al, in which the central macular thickness was reduced by $42.85 \%$ and $32 \%$ respectively after single injection of TA. ${ }^{12,13}$ 
Refractory Diabetic Macular Edema

Table-II: Comparison of visual acuity, intraocular pressure and central macular thickness pre $(n=35)$ and post injection $(n=35)$.

\begin{tabular}{|c|c|c|c|c|c|}
\hline \multirow{2}{*}{ Variables } & \multirow{2}{*}{ Mean \pm SD } & \multirow{2}{*}{$p$-value } & \multicolumn{2}{|c|}{ 95\% Confidence Interval } & \multirow{2}{*}{ Effect Size } \\
\hline & & & Lower & Upper & \\
\hline \multicolumn{6}{|c|}{ Visual Acuity } \\
\hline $\begin{array}{l}\text { Pre } \\
\text { Post }\end{array}$ & $\begin{array}{l}1.00 \pm 0.36 \log \mathrm{mar} \\
0.71 \pm 0.25 \log \mathrm{mar}\end{array}$ & 0.001 & 0.16 & 0.39 & 1.17 \\
\hline \multicolumn{6}{|c|}{ Intra Ocular Pressure } \\
\hline $\begin{array}{l}\text { Pre } \\
\text { Post }\end{array}$ & $\begin{array}{l}14.75 \pm 2.45 \mathrm{~mm} \mathrm{Hg} \\
19.05 \pm 6.37 \mathrm{~mm} \mathrm{Hg}\end{array}$ & 0.002 & -6.83 & -1.76 & 0.8 \\
\hline \multicolumn{6}{|c|}{ Central Macular Thickness } \\
\hline $\begin{array}{l}\text { Pre } \\
\text { Post }\end{array}$ & $\begin{array}{l}514.5 \pm 132 \mathrm{~mm} \\
278.1 \pm 106 \mathrm{~mm}\end{array}$ & 0.001 & 173.8 & 299 & 1.7 \\
\hline
\end{tabular}

Visual acuity was also improved in current study that was in conformity with Lashy et al, study. ${ }^{14}$ Another study conducted by Mehmood et al, in Lahore Pakistan proved that visual acuity improves after administration of IVTA injection. IVTA is an alternate treatment for eye with DME refractory to medical and laser treatments. ${ }^{15}$

Paccola et al, found in his study which he conducted for comparing the effectiveness of TA injection with bevacizumab injection in reducing central macular thickness. Central macular thickness was significantly reduced in the IVT group as compared with the bevacizumab group. Visual acuity was significantly higher in the intravitreal triamcinolone group compared with the bevacizumab group. Single intravitreal injection of triamcinolone may have better effen ct with respect to central macular thickness changes as compared to bevacizumab in the short-term management of refractory DME. ${ }^{16}$

The only complication in current study was found to be rise in intraocular pressure and similar complications were reported by Kanon somnaz and Vasconcelos et al, who reported rise in IOP as the most common complication of administering IVTA. ${ }^{17,18}$ Paccola et al, also found in his comparative study that IOP was significantly raised in group with triamcinolone injection as compared to bevacizumab. ${ }^{16}$ The elevation in IOP after steroid treatment is thought to be due to microstructral changes at the trabecular meshwork which cause an increased resistance to aqueous outflow. ${ }^{19}$

Jonas et al, reported in a study that patients who received IVTA, up to $50 \%$ had raised IOP. Most patients after an initial injection do not have a raised IOP and did not report rise in pressure with even further injections. ${ }^{20}$

\section{CONCLUSION}

Central macular thickness was decreased and visual acuity was significantly improved after IVT injections in patients with DM.

\section{Conflict of Interest: None.}

\section{Authors' Contribution}

AAG: Conception of idea, drafting of synopsis, data collection, US: Methodology write up, Data cleaning, data entry, analysis of data, results write up, referencing, $\mathrm{KH}$ : Literature review, Introduction write up, data collection, ZKOK: Data collection, final write up and review of the draft.

\section{REFERENCES}

1. Global report on diabetes. Who.int. 2016, [Internet] Available from: <https://www.who.int/publications-detail-redirect/ 9789241565257> [Accessed 8 July 2019].

2. Sughra U, Imran M. Co-morbid depression in individuals with type 2 diabetes mellitus. J Pak Med Assoc 2018; 68(1): 109-111.

3. Yau JW, Rogers SL, Kawasaki R, Lamoureux EL, Kowalski JW, Bek T, et al. Global prevalence and major risk factors of diabetic retinopathy. Diabetes Care 2012; 35(3): 556-564.

4. Ip MS, Domalpally A, Hopkins JJ, Wong P, Ehrlich JS. Long-term effects of ranibizumab on diabetic retinopathy severity and progression. Arch Ophthalmol 2012; 130(9): 1145-1152.

5. Thomas B, Shienbaum G, Boyer D, Flynn H. Evolving strategies in the management of diabetic macular edema: clinical trials and current management. Canadian J Ophthalmol 2013; 48(1): 22-30.

6. Chen E, Looman M, Laouri M. Burden of illness of diabetic macular edema: literature review. Curr Med Res Opin 2010; 26(7): 1587-1597.

7. Hinai AA, Wali UK, Rasool TA, Rizwi SG. Experience of intravitreal triamcinolone acetonide for treatment of diabetic macular edema among Omani population. Oman J Ophthalmol 2017; 10(3): 177-183.

8. David AA, Klein R, Gardner TW. Diabetic retinopathy. N Engl J Med 2012; 366(13): 1227-1239.

9. Ciardella A , Klancnik J, Schiff W, Barile G, Langton K, Chang S Intravitreal triamcinolone for the treatment of refractory diabetic ma-cular oedema with hard exudates: an optical coherence tomography study. Br J Ophthalmol 2004; 88(9): 1131-1136.

10. Fernando A. Intravitreal Triamcinolone Acetonide for Refractory Diabetic Macular Oedema. J R Soc Med 2005; 98(9): 421-422.

11. Martidis A, Duker JS, Greenberg PB. Intravitreal triam-cinolone for refractory diabetic macular edema. Ophthalmol 2002; 109(5): 920-927.

12. Kramar M, Lani Vu. The effect of intravitreal triamcino-lone on intraocular pressure. Curr Med Res Opin 2007; 23(6): 1253-1258.

13. Williamson THO, Donnell A. Intravitreal triamcinolone acetonide for cystoid macular edema in nonischemic central retinal vein occlusion. Am J Ophthalmol 2005; 139(5): 860-866.

14. Lasha A, Jalili MH, Nili-Ahmadabadi M, Mirshahi A, Faghihi H, Ali. Effect of intravitreal triamcinolone acetonide on visual acuity and macular thickness in macular edema associated with non 


\section{Refractory Diabetic Macular Edema}

ischemic central retinal vein occlusion. Irani J Ophthalmol 2006; 19(2): 6-11.

15. Mehmood K, Malik BA, Khan MT. Visual effects of intravitreal triamcinolone acetonide injection in patients with refractory diabetic macular edema. Pak J Ophthalmol 2010; 26(4): 1-5.

16. Vasconcelos-Santos DV, Nehemy PG, Schachat AP. Secondary ocular hypertension after intravitreal injection of $4 \mathrm{mg}$ of triamcinolone acetonide: incidence and risk factors. Retina 2008; 28(4): 573-580.

17. Sonmez K, Ozturk F. Complications of intravitreal triamcinolone acetonide for macular edema and predictive factors for intraocular pressure elevation. Int J Ophthalmol 2012; 5(6): 719-725.
18. Clark AF, Brotchie D, Read AT, Hellberg P, English-Wright S, Pang $\mathrm{IH}$, et al. Dexamethasone alters F-actin architecture and promotes cross-linked actin network formation in human trabecular mesh-work tissue. Cell Motil Cytoskeleton 2005; 60(2): 83-95.

19. Jonas JB, Kreissig I, Sofker A, Degenring RF. Intravitreal injection of triamcinolone for diffuse diabetic macular edema. Arch Ophthalmol 2003; 121(1): 57-61.

20. Ip MS, Domalpally A, Sun JK, Ehrlich JS. Long-term effects of therapy with ranibizumab on diabetic retinopathy severity and baseline risk factors for worsening retinopathy. Ophthalmol 2015; 122(2): 367-374. 